\section{PENGARUH KINERJA} TERHADAP PELAKSANAAN

\section{DETEKSI PHEIC}

(Public Health Emergency of International Concern)

Pembangunan kesehatan saat ini terus ditingkatkan guna pencegahan dan penanggulangan potensial wabah terutama di bagian wilayah pelabuhan dan bandara, merupakan pintu masuk dan keluar lalu lintas orang, barang dan jasa dari satu daerah ke daerah lain atau dan satu negara ke negara lain. Timbulnya epidemi global (pandemi) khususnya menuntut dikembangkannya jejaring yang terpadu di seluruh dunia, yang manyatukan para praktisi kesehatan, peneliti, pemerintah, dan organisasi internasional. untuk memperhatikan kebutuhan-kebutuhan surveilans yang melintasi batas-batas negara. Surveilans di pintu masuk dilakukan untuk mendeteksi dini dan respon serta memastikan wilayah bandara, pelabuhan, bandara dan lintas batas negara dalam keadaan tidak ada transmisi virus. International Health Regulation (IHR) tahun 2005 yang diberlakukan 15 Juni Tahun 2007 dengan perhatian kepada Public Health Emergency of International Concern IPHIEC (masalah kedaruratan kesehatan masyarakat yang menjadi perhatian global) mempersyaratkan agar pelabuhan, bandara dan perlintasan darat dapat merespons kejadian yang dapat menimbulkan PHEIC. Dampak penyakit infeksi emerging semakin besar bila terjadi di negara berkembang yang relatif memiliki sumber daya lebih terbatas dengan ketahanan sistem kesehatan masyarakat yang tidak sekuat negara maju. Indonesia sebagai negara anggota World Health Organization (WHO) telah menyepakati untuk melaksanakan ketentuan International Health Regulations (IHR) 2005, dan dituntut harus memiliki kemampuan dalam deteksi dini dan respon cepat terhadap munculnya penyakit/kejadian yang berpotensi menyebabkan kedaruratan kesehatan masyarakat yang meresahkan dunia tersebut. Untuk meningkatkan mutu penyelenggaraan penanggulangan penyakit menular, dibutuhkan strategi innovative dengan memberikan otoritas pada petugas kesehatan masyarakat (Public Health Officers) terutama hak askes pengamatan factor risiko dan penyakit serta penentuan langkah penanggulangannya

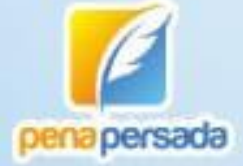

Dr. Asriwati, S.Kep, Ns,S.Pd, M.Kes

Rakhmad Kurnia Putra, P.SKM, M.M, M.KM

PENGARUH KINERJA TERHADAP PELAKSANAAN DETEKSI PHEIC

(Public Health Emergency of International Concern) 


\title{
PENGARUH KINERJA TERHADAP PELAKSANAAN DETEKSI PHEIC \\ (Public Health Emergency ofInternational Concern)
}

\author{
Dr. Asriwati, S.Kep, Ns,S.Pd, M.Kes \\ Rakhmad Kurnia Putra, P.SKM, M.M, M.KM
}

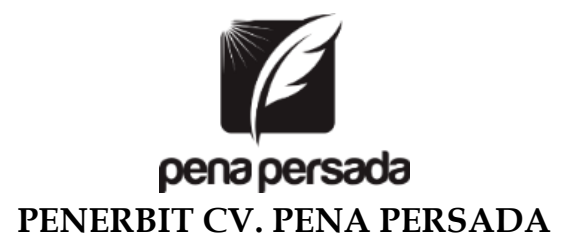




\title{
PENGARUH KINERJA TERHADAP PELAKSANAAN \\ DETEKSI PHEIC \\ (Public Health Emergency ofInternational Concern)
}

\author{
Penulis: \\ Dr.Asriwati, S.Kep, Ns,S.Pd, M.Kes \\ Rakhmad Kurnia Putra, P.SKM, M.M, M.KM
}

ISBN : 978-623-315-304-1

Editor:

Wiwit Kurniawan

Design Cover :

Retnani Nur Briliant

Layout :

Eka Safitry

\section{Penerbit CV. Pena Persada \\ Redaksi :}

Jl. Gerilya No. 292 Purwokerto Selatan, Kab. Banyumas

Jawa Tengah

Email : penerbit.penapersada@gmail.com

Website : penapersada.com Phone : (0281) 7771388

\section{Anggota IKAPI}

All right reserved

Cetakan pertama : 2021

Hak Cipta dilindungi oleh undang-undang. Dilarang memperbanyak karya tulis ini dalam bentuk apapun tanpa izin penerbit 


\section{KATA PENGANTAR}

Segala puji senantiasa kita panjatkan kehadirat Allah Swt, atas segala rahmat dan karunianya, akhirnya penulis dapat menyelesaikan penyusunan buku yang berjudul " PENGARUH KINERJA TERHADAP PELAKSANAAN DETEKSI PHEIC (Public Health Emergency ofInternational Concern)". Saya menyadari bahwa tanpa bantuan dan bimbingan dari berbagai pihak sangatlah sulit bagi saya untuk menyelesaikan karya ini. Oleh karena itu, saya mengucapkan banyak terima kasih pada semua pihak yang telah membantu penyusunan buku ini. Sehingga buku ini bisa hadir di hadapan pembaca.

Dalam buku ini membahas tentang pengaruh kinerja terhadap pelaksanaan deteksi PHEIC padda KKP Kelas I Medan Tahun 2020. Faktor-faktor yang mempengaruhi kinerja karyawan, sangat penting untukd iperhatikan karena merupakan salah satu cara untuk meningkatkan kualitas sumber daya manusia (karyawan). Telah dilakukan kajian dengan desain kajian observasional dengan pendekatan cross sectional terhadap 56 respoden dengan menggunakan uji corelasi. Hasil kajian menunjukkan bahwa ada hubungan kinerja berdasarkan disiplin terhadap pelaksanaan deteksi PHEIC. Disarankan kepada seluruh pegawai untuk lebih menegakkan disiplin dan bagi pegawai yang melanggar ketentuan dan peraturan hendaknya dipertimbangkan dengan cermat dan teliti bahwa hukuman yang akan dijatuhkan sesuai dengan tindakan dan perilaku yang diperbuat dan adanya pengawasan yang efektif dalam meningkatkan kinerja pegawai, kepada pimpinan agar benar-benar mengawasi pekerjaan dari setiap pegawai dengan tepat tanpa menyimpang dari sistem yang dibuat dan memastikan bahwa aktivitas yang dipantau akan mencapai tujuan.

Penulis menyadari bahwa buku ini masih jauh dari kesempurnaan. Oleh karena itu kritik dan saran yang membangun sangat dibutuhkan guna penyempurnaan buku ini. Akhir kata saya berharap Tuhan Yang Maha Esa berkenan membalas segala kebaikan semua pihak yang telah membantu

\section{Penulis}




\section{DAFTAR ISI}

KATA PENGANTAR

DAFTAR ISI iv

BAB I PENDAHULUAN 1

A. Penilaian Kinerja Pegawai 1

B. Penularan Penyakit Lintas Batas Negara 2

BAB II DETEKSI PHEIC (Public Health Emergency of International Concern)

A. Konsep Deteksi Dini dan Respon di Pintu Masuk Negara 11

B. Alat Angkut (Kapal, pesawat dan Alat Angkut Darat) 12

C. Penumpang dan Awak 12

D. Barang Bawaan 13

E. Lingkungan Pelabuhan atau Bandara $\quad 14$

BAB III KINERJA $\quad 15$

A. Pengertian Kinerja $\quad 15$

B. Faktor-faktor Eksternal yang Mempengaruhi Kinerja 18

C. Prinsip-prinsip Penilaian $\quad 21$

BAB IV DisiplinKerja $\quad 23$

A. Definisi Disiplin Kerja 23

B. Karakteristik Disiplin Kerja 24

C. Indikator Disiplin Kerja 25

D. Faktor-faktor yang Memengaruhi Disiplin Kerja 25

BAB V Budaya Organisasi 26

A. Definisi Budaya Organisasi 26

B. Karakteristik Budaya Organisasi 27

C. Indikator Budaya Organisasi 28

D. Faktor-faktoryang Mempengaruhi Budaya Organisasi 30 BAB VI PENGAWASAN 32

A. Pengertian Pengawasan 32

B. Fungsi Pengawasan 33

C. Langkah-Langkah dalam Pengawasan 33 
D. Jenis-jenis Pengawasan 35

E. Tujuan Pengawasan 35

BAB VII PENGARUH KINERJA TERHADAP PELAKSANAAN DETEKSI PHEIC KANTOR KESEHATAN PELABUHAN $\quad 37$

A. Gambaran Umum Kantor Kesehatan Pelabuhan Kelas I Medan

B. Hubungan Kinerja Berdasarkan Disiplin Terhadap

Pelaksanaan Deteksi PHEIC

C. Hubungan Kinerja Berdasarkan Pengawasan Terhadap

Pelaksanaan Deteksi PHEIC

D. Hubungan Kinerja Berdasarkan Budaya Organisasi

Terhadap Pelaksanaan Deteksi PHEIC

E. Pengaruh Kinerja Terhadap Pelaksanaan Deteksi PHEIC 51

BAB VIII PENUTUP

DAFTAR PUSTAKA 


\section{PENGARUH KINERJA TERHADAP PELAKSANAAN DETEKSI PHEIC}

(Public Health Emergency ofInternational Concern) 


\section{BAB I \\ PENDAHULUAN}

\section{A. Penilaian Kinerja Pegawai}

Kinerja merupakan hasil olah pikir dan tenaga dari seorang karyawan terhadap pekerjaan yang dilakukannya, dapat berujud, dilihat, dihitung jumlahnya, akan tetapi dalam banyak hal hasil olah pikiran dan tenaga tidak dapat dihitung dan dilihat, seperti ide-ide pemecahan suatu persoalan,inovasi baru suatu produk barang atau jasa, bisa juga merupakan penemuan atas prosedur kerja yang lebih efisien. Kinerja adalah suatu hasil kerja yang dicapai seseorang dalam melaksanakan tugas-tugas yang dibebankan kepadanya yang berdasarkan atas kecakapan, pengalamandan kesungguhan serta waktu. Kinerja merupakan gabungan dari tiga faktor penting yaitu kemampuan minat seorang pekerja, kemampuan dan penerimaan atas penjelasan delegasi tugas, serta peran dan tingkat motivasi seorang pekerja.

Penilaian kinerja adalah "suatu sistem melalui mana organisasi mengevaluasi atau menilai kinerja karyawan yang sesuai dengan kinerja mereka masing-masing kepada perusahaan. Sistemini bertujuan untuk memotivasi parakaryawan agar bisa meningkatkan kinerja. Oleh karena itu kinerja yang baik tidak hanya individunya saja yang menguntungkan, akan tetapi lembaga institusi atau organisasi maupun masyarakat juga akan mendapatkan keuntungan. Hal ini menunjukkan bahwa penggunaan sistem informasi dalam organisasi atau lembaga institusi sangat dibutuhkan. Salah satunya adalah penelitian yang menyangkut kinerja karyawan yang diyakini merupakan salah satu kunci keberhasilan dalam organisasi. 
Faktor-faktor yang mempengaruhi kinerja karyawan, penting sekali untuk diperhatikan karena merupakan salah satu cara untuk meningkatkan kualitas sumber daya manusia (karyawan). Faktor-faktor yang mempengaruhi kinerja adalah motivasi, pelatihan dan pendidikan, kompensasi, teknologi, ketrampilan dan disiplin kerja. Globalisasi dan modernisasi dalam bidang industri hampir menyisihkan keinginan karyawan yang mau bekerja, namun demikian karyawan akan tetap dibutuhkan oleh perusahaan, sebabtanpa karyawan suatu perusahaan mustahil dapat berjalan dengan sendirinya. Karyawan selalu terlibat dalam setiap proses manajemen maupun operasional dalam sebuah perusahaan, keterkaitan kompensasi dengan kinerja karyawan sangatlah signifikan. Organisasi menerapkan sistem kompensasi secara fleksibel dan bebas sesuai dengan kondisi masing-masing. Sistem manayang dirasa tepat untuk memberikan kompensasi kepada pekerja dengan harapan dapat meningkatkan kinerja. Kompensasi dalam bentuk finansial adalah penting bagi karyawan, sebab dengan kompensasi ini mereka dapat memenuhi kebutuhannya secara langsung, terutama kebutuhan fisiologisnya. Namun demikian, tentunya pegawai juga berharap agar kompensasi yang diterimanya sesuai dengan pengorbanan yang telah diberikan. Kompensasi dalam bentukn onfinansial juga sangat penting bagi pegawai terutama untuk pengembangan karirmereka.

\section{B. Penularan Penyakit Lintas Batas Negara}

Kedaruratan Kesehatan Masyarakat yang Meresahkan Dunia atau disingkat KKMD (bahasa Inggris: Public Health Emergency of International Concern, PHEIC) adalah pengumuman resmi Organisasi Kesehatan Dunia (WHO) tentang "kejadian luar biasa yang berisiko mengancam kesehatan masyarakat negara lain melalui penularan penyakit lintas batas negara dan membutuhkan tanggapan internasional yang terkoordinasi". Pengumuman ini dirancang ketika sebuah kejadian bersifat "serius, mendadak, 
tidak wajar, atau tidak terduga", "dapat mempengaruhi kesehatan masyarakat di luar batas negara terdampak", dan "perlu ditanggapi segera oleh berbagai negara" Menurut Peraturan Kesehatan Internasional (IHR) 2005, setiap negara wajib menanggapi PHEIC sesegera mungkin. Pengumuman ini diterbitkan oleh Komite Darurat (Emergency Committee) yang beranggotakan ilmuwan dari seluruh dunia sesuai IHR 2005. Peraturan ini dikembangkan usai wabah SARS 2002/2003. Sejak 2009, ada enam pengumuman PHEIC: pandemi flu 2009, pengumuman polio 2014, wabah virus Ebola di Afrika Barat, wabah virus Zika 2015-2016wabah Ebola Kivudan wabah koronavirus baru 20192020.Rekomendasinya bersifat sementara dan wajib ditinjau ulang tiga bulan sekali.Penyakit SARS, cacar air, poliomielitistipe liar, dan segala subtipe baru influenza manusia otomatis dianggap PHEIC dan tidak memerlukan keputusan IHR.

Saat ini salah satu penyakit yang tergolong dalam KKMMD/PHEIC adalah Corona Virus -19 (Covid-19). Coronavirus Disease 2019 (COVID-19) adalah penyakit menular yang disebabkan oleh Severe Acute Respiratory Syndrome Coronavirus 2 (SARS-CoV-2). Pada tanggal 30 Januari 2020 WHO menetapkan kejadian tersebut sebagai Kedaruratan Kesehatan Masyarakat yang Meresahkan Dunia (KKMMD)/Public Health Emergency of International Concern(PHEIC) dan pada tanggal 11 Maret 2020, WHO sudah menetapkan COVID-19 sebagai pandemi.Sampai dengan tanggal 9 Juli2020, WHO melaporkan 11.84 .226 kasus konfirmasi dengan 545.481 kematian di seluruh dunia (Case Fatality Rate/CFR 4,6\%). Indonesia melaporkan kasus pertama pada tanggal 2 Maret 2020. Kasus meningkat dan menyebar dengan cepat di seluruh wilayah Indonesia. Sampai dengan tanggal 9 Juli 2020 Kementerian Kesehatan melaporkan 70.736 kasus konfirmasi COVID-19 dengan 3.417 kasus meninggal (CFR 4,8\%).Pemerintah Indonesia telah menetapkan Keputusan Presiden Nomor 11 Tahun 2020 tentang Penetapan 
Kedaruratan Kesehatan Masyarakat Corona Virus Disease2019 (COVID-19). Keputusan Presiden tersebut menetapkan COVID-19 sebagai jenis penyakit yang menimbulkan Kedaruratan Kesehatan Masyarakat (KKM) dan menetapkan COVID-19 di Indonesia yang wajib dilakukan upaya penanggulangan sesuai ketentuan peraturan perundang-undangan. Keputusan Presiden Nomor 12 Tahun 2020 tentang Penetapan Bencana Nonalam Penyebaran Corona Virus Disease 2019 (COVID-19) Sebagai Bencana Nasional. Penanggulangan KKM dilakukan melalui penyelenggaraan kekarantinaan kesehatan baik di pintu masuk maupun di wilayah.

Kebutuhan SDM dalam Penanggulangan kedaruratan kesehatan masyarakat mengacu kepada Permenkes NO 1501 Tahun 2010 Tentang Jenis Penyakit Menular Tertentu yang dapat menimbulkan Wabah dan Upaya Penanggulangan. TGC terdiri dari tenaga medis, tenaga epidemiolog, tenaga entomology, tenaga sanitarian dan tenaga laboratorium, selain itu TGC juga melibatkan tenaga pada program atau sector terkait.

Pelaksanaan cegah tangkal penyakit menular terkait dengan kekarantinaan kesehatan, sangat penting untuk dipahami oleh semua pegawai KKP Kelas I Medan dalam pengendalian dan penanggulangan penyakit menular terutama Kedaruratan Kesehatan Masyarakat Yang Meresahkan Dunia (KKMMD) yang semakin besar dan kompleks. Hal ini terjadi seiring dengan meningkatnya pergerakan dan perpindahan penduduk sebagai dampak peningkatan pembangunan serta perkembangan teknologi transportasi, dengan demikian kecepatan waktu tempuh perjalanan antar negara dapat melebihi masa inkubasi penyakit. Kondisi ini akan memperbesar risiko masuk dan keluarnya penyakit terutama penyakit infeksi emerging. 
Sebagai salah satu penyelenggara pembangunan kesehatan di Indonesia, Kantor Kesehatan Pelabuhan (KKP) adalah merupakan unit pelaksanaan teknis di bidang pemberantasan penyakit menular. Sesuai dengan International Health Regulation (IHR) tahun 2005 yang diberlakukan 15 Juni Tahun 2007 sampai saat ini dengan perhatian kepada Public Health Emergency Of International Concern /PHIEC ( masalah kedaruratan kesehatan masyarakat yang menjadi perhatian global) memberikan perhatian khusus untuk wilayah pelabuhan dengan menetapkan persyaratan kapasitas inti bandara, pelabuhan dan perlintasan darat agar setiap saat menjamin lingkungan yang aman bagi para pelaku perjalanan yang menggunakan fasilitas yang ada di pintu masuk.

Pelaksanaan penanggulangan ataupun pelaksanaan deteksi dini penyakit PHEIC membutuhkan penanganan yang sangat serius untuk mencegah adanya penyebaran virus dari orang ke orang, beberapa usaha yang dilakukan dalam upaya antisipatif untuk menangkal persebaran virus seperti sejumlah bandara di Indonesia mengaktifkan alat pendeteksi suhu tubuh (thermo scanner) di area terminal kedatangan internasional sebagai alat pendeteksi suhu tubuh ini dilakukan sesuai dengan prosedur yang diamanatkan Undang-Undang Nomor 6 Tahun 2018 tentang Kekarantinaan Kesehatan, bahwa setiap pesawat luar negeri harus diawasi. Selain itu, penumpang yang masuk ke bandara harus melalui tahapan pendeteksi tubuh dan dilakukan karantina.

Dalam pelaksanaan pekerjaan di Kantor Kesehatan Pelabuhan dibutuhkan pegawai-pegawai yang memiliki kinerja, terutama dalam hal disiplin kerja, serta membutuhkan pengawasan yang baik dari pimpinan setiap bagian yang ada. Selain dari disiplin kerja dan pengawasan faktor yang tak kalah mendukung dalam menjalankan pekerjaan tersebut adalah budaya organisasi, dengan budaya organisasi yang baik akan menciptakan kinerja pegawai yang baik pula. 
Kinerja pegawai merupakan suatu hasil kerja yang dicapai seseorang dalam melaksanakan tugas-tugas yang dibebankan kepadanya yang didasarkan atas kecakapan, pengalaman dan kesungguhan serta waktu. Menurut Kinerja pegawai ini adalah "Gabungan dari tiga faktor penting yaitu kemampuan dan minat seseorang pekerja, kemampuan dan penerimaan atas penjelasan delegasi tugas dan peran serta pimpinan". Semakin tinggi ketiga faktor di atas, maka semakin besarlah kinerja pegawai bersangkutan.(1)

Salah satu permasalahan penting yang dihadapi pimpinan adalah bagaimana dapat meningkatkan kinerja pegawainya sehingga dapat mendukung keberhasilan pencapaian tujuan. Pimpinan yang baik adalah mampu menciptakan suatu kondisi sehingga orang secara individu atau kelompok dapat bekerja dan mencapai kinerja yang tinggi. Permasalah peningkatan kinerja erat kaitannya dengan permasalahan bagaimana disiplin pegawai diterapkan, bagaimana pengawasan dilakukan dan bagaimana cara mengembangkan budaya kerja yang efektif, agar pegawai dapat dan mau bekerja optimal dan sehingga dapat mendukung pencapaian tujuan perusahaan.

Adapun fenomena yang ditemui pada Kantor Kesehatan Pelabuhan Kelas I Medan adalah hasil kerja dari beberapa pegawai yang masih sering terjadi kesalahan kerja seperti laporan yang tidak diselesaikan dengan benar, selain itu beberapa pegawai tidak dapat menyelesaikan pekerjaan tepat pada waktunya yang melewati ketentuan dari target pelaporan yang telah ditetapkan, fenomena lain yang ada di kantor berdasarkan laporan Kepala Sub Bagian Kepegawaian dan Umum adalah persentase ketidak hadiran pegawai yang cukup tinggi yaitu sebesar 5,5\% dari jumlah pegawai setiap harinya sehingga hal ini mempengaruhi tingkat kinerja dari pegawai tersebut. Selain tingkat ketidakhadiran pegawai yang cukup tinggi, terdapat juga beberapa pegawai yang sering terlambat hadir ke kantor walaupun sistem absensi telah menggunakan alat yang otomatis tetapi tidak dapat meningkatkan disiplin pegawai. (8) 
Menurunnya disiplin kerja di Kantor Kesehatan Pelabuhan Kelas I Medan merupakan salah satu indikasi dari terbentuknya budaya lemah yang menunjukkan nilai-nilai ketaatan, kepatuhan, kesetiaan, keteraturan dan atau ketertiban.

Permasalahan mendasar yang berkaitan dengan disiplin kerja di Kantor Kesehatan Pelabuhan Kelas I Medan adalah masih tingginya tingkat keterlambatan pegawai pada jam kantor yang telah ditetapkan.Selain itu, masih banyak pegawai yang memanfaatkan waktu istirahat melebihi waktu yang telah ditetapkan oleh kantor. (8)

Dalam meningkatkan kemampuan pegawai perlu dilakukan dengan monitoring dan evaluasi terhadap pegawai terutama yang menduduki jabatan fungsional dengan memberikan atau mengikuti pelatihan yang sesuai dengan pendidikan dan fungsional serta tugas dan fungsi dari pegawai tersebut sehingga diharapkan mampu berinovasi dan meningkatkan semangat kerja.

Permasalahan lain yang berkaitan dengan budaya organisasi ini adalah kebiasaan mayoritas pegawai mangkir dari pekerjaannya. Hal ini terlihat dari banyaknya tugas-tugas yang tidak terselesaikan tepat pada waktu yang telah ditetapkan oleh perusahaan. Selain itu, beberapa peraturan yang ada masih belum ditaati sepenuhnya oleh sebagian pegawai. Kurangnya tindakan tegas dari kepala Kantor Kesehatan Pelabuhan Kelas I Medan menjadikan hal ini sebagai kebiasaan yang kemudian berangsur menjadi budaya lemah yang akan terbentuk di lingkungan pegawai. Tindakan yang harus diberikan oleh seorang pimpinan terhadap pegawai yang mangkir dari pekerjaan, tidak berada di tempat kerja pada saat jam kerja serta tidak menyelesaikan tugas yang diberikan oleh atasan dapat berupa tindakan pemotongan Tunjangan Kinerja, pemberian Surat Peringatan serta dapat bisa saja terjadi pemindahan pegawai ke Wilayah Kerja di lingkungan KKP Kelas I Medan serta penundaan kenaikan pangkat. 
Beberapa permasalahan yang dihadapi Kantor Kesehatan Pelabuhan Kelas I Medan secara perlahan dapat menimbulkan dampak berupa menurunkan kinerja pegawai. Belum adanya pengambilan tindakan berkaitan dengan pemecahan masalah ini dikhawatirkan dapat mempengaruhi kinerja pegawai lain yang memiliki keinginan untuk bekerja dengan baik dan sungguh-sungguh.

Demikian pentingnya pengawasan dalam sebuah organisasi instansi pemerintahan, menjadikan hal ini perlu dianggap sebagai suatu hal yang serius. Banyak terjadi di lapangan, pengawasan yang tidak dilakukan dengan baik seperti kurangnya perhatian pimpinan terhadap jam masuk dan jam keluar pegawai serta pengawasan terhadap pekerjaan yang diberikan, berakibat pada rendahnya kinerja pegawai, dan berdampak kepada kegagalan dalam mencapai tujuan instansi pemerintahan. Berdasarkan jam masuk kerja Hari Senin s,d Kamis Jam masuk pukul 7.30 WIB s.d 14.00 WIB dan Hari Jumat Pukul 07.30 WIB s,d 14.30 WIB, berdasarkan persentase kehadira tepat waktu pada tahun 2019 sebanyak 74,13 \% dan pada Tahun 2020 sampai Bulan Juni sebesar $77,58 \%$. disamping itu masih ada pegawai yang hanya datang melakukan pingerprint pada pagi dan sore hari tanpa ada di tempat kerja, artinya pegawai hanya melakukan absensi pagi selanjutnya pulang atau meninggalkan tempat kerja dan sore harinya melakukan absen kembali, melihat hal ini belum adanya pengawasan terhadap pegawai yang demikian atau belum adanya pengawasan yang terhadap pegawai yang mangkir dari tempat kerja dengan absensi yang baik.(8)

Budaya organisasi di KKP Kelas I Medan dalam melaksanakan tugas dan fungsi setiap harinya tidak dapat dijalankan secara sendiri-sendiri tetapi harus bekerja secara team, disamping itu harus mengikuti SOP yang telah ditetapkan serta mengikutsertakan stakeholder dalam melaksanakan tugas dan fungsi, karena pelabuhan dan bandara merupakan pintu masuk negara yang memiliki 
pengawasan yang sangat ketat serta pelaksanaan implementasinya harus berkoordinasi dengan pihak Stakeholder seperti PELINDO, SYAHBANDAR, AIRLINE dan atau pihak agen kapal, sehingga dalam pelaksanaan tugasnya harus melaksanakan analisis dalam proses serta cepat dalam menilai dan memberi tindakan terhadap hal-hal yang kasus.(7)

Pengawasan sebagaimana diatur dalam Pasal 35 UU No. 25/2009 tentang Pelayanan Publik, terdiri dari 2 yaitu pengawas internal dan pengawas eksternal. Pengawas internal terdiri dari Atasan Langsung dan Pengawas Fungsional lalu untuk pengawas eksternal terdiri dari masyarakat, Ombudsman dan DPR. pengawas eksternal dalam hal ini masyarakat, dilakukan berupa laporan atau pengaduan atas penyelenggaraan pelayanan publik. Ini menunjukkan pentingnya sebuah sarana pengaduan yang dapat menjadi bagian dari kontrol atau pengawasan publik.

Dengan demikian, peneliti melihat bahwa masalah disiplin kerja, pengawasan dan budaya organisasi merupakan permasalahan yang penting dalam sebuah instansi pemerintahan. Pelaksanaan pengawasan yang dilaksanakan oleh pegawai KKP Kelas I Medan adalah penanganan dan pencegahan penyakit melalui pengukuran suhu tubuh dan memeriksa hasil pemeriksaan Rapid Test terhadap penumpang naik ke pesawat dan kapal laut, karena ini merupakan syarat utama bagi penumpang untuk dapat melanjutkan perjalanan lewat pesawat dan kapal laut, dan bagi penumpang turun dari pesawat dan Kapal Laut pegawai KKP memeriksa suhu tubuh melalui Thermal Scanner serta mengumpulkan kartu kuning atau disebut dengan Health Alert Card yang berisikan tentang data-data penumpang sehingga dapat membantu petugas untuk melaksanakan traccing apabila penumpang yang bersangkutan mengalami sakit atau gejala gejala penyakit covid-19 dalam 14 hari kedepan, sehingga dengan proses seperti ini dapat menekan sedini mungkin penyebaran penyakit yang berhubungan 
dengan penyakit PHEIC. Untuk itu penulis menjadikan permasalahan ini sebagai sebuah penelitian dengan judul Pengaruh Kinerja Terhadap Pelaksanaan Deteksi PHEIC (Public Health Emergency of International Concern ) Pada Kantor Kesehatan Pelabuhan Kelas I Medan Tahun 2020". 


\section{BAB II \\ DETEKSI PHEIC (Public Health Emergency of International Concern)}

\section{A. Konsep Deteksi Dini dan Respon di Pintu Masuk Negara}

Sistem surveylans epidemiologi di Pintu Masuk Negara adalah kegiatan proses pengumpulan, pengolahan, analisis, dan interpretasi data secara sistematik dan terus menerus terhadap penyakit karantina.penyakit karantina yang dimaksud adalah penyakit yang berpotensi menjadi wabah dan masalah kesehatan pada suatu wilayah dan masuk melalui pintu masuk Negara. Kepadatan aktivitas dipintu masuk Negara memperbesar risiko terjadinya peningkatan dan penularan penyakit, serta masalah kesehatan lainnya. Penyebaran informasikepada unit yang berpentingan sangat ddiperlukan utamanya dalam mengambil tindakan yang efektif dan efisien dalam penanggulangan penyakit.

Dalam rangka implementasi IHR (2005) dipelabuhan, bandara dan PLBD, upaya pencegahan dilakukan melalui pengendalian factor risiko, pengendalian factor risikodi lakukan secara rutin terhadap kondisi sanitasi di pelabuhan dan alat angkut termasuk pengendalian vector. Upaya deteksi dini dilakukan dengan mendeteksi kejadian melalui pemeriksaan dan pengawasan, skrining, informasi dan perifikasi terhadap penumpang, alat angkut dan factor risiko penyakit. Upaya respon dilakukan dengan merespon kedaruratan kesehatan masyarakat melalui pelaksanaan penyelidikan epidemiologi dan aktivasi rencana kontijensi terhadap KKMD. Pengawasan Kedatangan dilakukan terhadap alat angkut, orang dan barang yang datang dari Negara terjankit termasuk pengawasan lingkungan pada pintu masuk. 


\section{B. Alat Angkut (Kapal, pesawat dan Alat Angkut Darat)}

Pengawasan terhadap alat angkut yaitu kapal laut, pesawat udara dan alat angkut darat (bus dan mobil) dilakukan sesaat setelah alat angkut tersebut tiba diarea pemeriksaan karantina, dengan memperhatikan hal-hal sebagai berikut :

1. Pelabuhan/bandara/daerah singgah terakhir tujuannya adalah untuk memastikan ada atau tidak wabah /KLB penyakit menular diwilayah tersebut (affected area).

2. Asal alat angkut dengan tujuan untuk menentukan riwayat perjalanan yang pernah dilakukan.

3. Dokumen kesehatan alat angkut diataranya General Declaration, Maaritim Declartion of Helath (MDH), Ship Sanitary Certificate Exemption Controln(SSCEC), Ship Sanitary certificate Control (SSCC), internasional certificate Of vaccination (ICV), medical certivicate, Port Helath Clereance (PHC), Free pratique, sertifikat air bersih dan sertifikat lainnya

4. Sanitasi alat angkut. Pengawasan sanitasi pada alat angkut dilakukan menyeluruh pada setiap ruang yang ada pada alat angkut. Apabila ditemukan factor risiko penularan penyakit maka harus dilakukan tindakan penyehatan pada alat angkut

\section{Penumpang dan Awak}

Penumpang merupakan factor risiko yang paling rentan terhadap perjalanan suatu penyakit menular potensial wabah. Oleh sebab itu ada hal-hal yang perlu diperhatikan :

1. Ada tidaknya penumpang dan awak yang sedang sakit,

2. Ada tidaknya penumpang dan awak yang menderita penyakit menular potensial wabah

3. Jumlah penumpang dan awak yang sedang sakit menular.

4. Jenis penyakit menular yang menyerang penumpang dan awak. 
5. Ada tidaknya penumpang dan awak yang berasal dari wilayah terjangkit suatu penyakit menular.

Penggunaan alat pemindai suhu tubuh (thermal scanner) disetiap pelabuhan dan bandara dapat membantu petugas dalam melakukan proses skrining tahap awal. Skring dilakukan dalam rangka deteksi dini penumpang yang sakit dengan gejala suhu tubuh diatas normal. Apabila ditemukan suspect padapenumpang, maka petugas harus segera melakukan rujukan pasien ke rumah sakit yang telah ditunjuk untuk dilakukan pemeriksaan lanjutan serta konfirmasi laboratorium.

\section{Barang Bawaan}

Barang yang di bawa penumpang maupun awak merupakan factor risiko munculnya penyakit menular potensial wabah. Barang bawaan dapat mengandung kontaminasi penyakit menular, mengadung unsur nuklir, biologi dan kimia (NUBIKA). Selain itu dilaksnakan pengawasan terhadap barang bawaan berupa obat, makanan, kosmetika, alat kesehatan dan Bahan Adiktif (OMKABA). Hal hal yang perlu diperhatikan terkait barang bawaan antara lain

1. Ada tidaknya agent penyakit dan factor risiko pada barang yang dibawa oleh penumpangbaik didalam kain maupun dibagasi,

2. Ada tidaknya bahan makanan/minuman mudah busuk/kadaluarsa yang terbawa penumpang di kabinmaupun dibagasi

3. Ada tidaknya binatang / tumbuhan yang mengandung factor risiko penyakit yang terbawa penumpang di kabin maupun bagasi

4. Jenazah, abu jenazah yang memiliki penyakit menular 